\title{
Productivity, pathogenicity, host range, and spore mass-propagation of local strain of Mattesia sp. isolated from insect cadavers of certain stored grain pests in Egypt
}

Ahlam Ahmed Alfazairy', Yasien Mohamed Gamal Zedan El-Abed ${ }^{2}$, Hanan Mohamed Ramadan ${ }^{3^{*}}$ (i) and Hedaya Hamza Karam ${ }^{1}$

\begin{abstract}
Average yields of Mattesia spores (spore productivity) had varied from a minimum yield $\left(0.17 \times 10^{7}\right.$ spores) for Laemophloeus turcicus adult to a maximum yield $\left(7.46 \times 10^{7}\right.$ spores $)$ for Plodia interpunctella larva. Comparatively, the highest increase in Mattesia spore yield, recorded from P. interpunctella larva $\left(7.46 \times 10^{7}\right.$ spores) over the lowest one, estimated for $L$. turcicus adult $\left(0.17 \times 10^{7}\right.$ spores), was nearly 44 -fold. The increase in Mattesia spore yields that calculated from the other hosts (P. interpunctella pupa or moth; Galleria mellonella larva; Rhyzopertha dominica adult; Sitophilus zeamais), over that estimated for L. turcicus adult, was less than 10-fold (6-9-fold). Based on the weight of $1 \mathrm{~g}$ of the insect host infected with Mattesia sp., small stored grain insect hosts (e.g. L. turcicus, S. zeamais, and $R$. dominica) seemed to achieve Mattesia spore yields more than the larger ones (e.g. P. interpunctella). The increase in spore yields over that used for the inoculum, based on an average of 25 P. interpunctella larvae per bioassay container, was ca. 2 to 31 -fold. These results revealed that the Indianmeal moth, $P$. interpunctella, could serve as a potential host for mass propagating the isolated entomopathogenic protozoan, Mattesia sp. Besides Mattesia larval mortality, survivors of Mattesia infection suffered deformities and noticeable undersized pupae or adults than the control ones. Also, many copulated moths (ca.46\%) were unable to become separated after copulation until they had died. Bioassay of siftings, obtained from L. turcicus-protozoan-infected stock cultures, was carried out in order to emphasize the suppressive potent role of such protozoan entomopathogens in long-term storage. With the highest tested concentration of the studied siftings (10\%), mortality responses due to Mattesia infection ranged from 13 to 68\% at 14-169 days post-treatment. The corresponding figures for Adelina infection were 7-42\%.
\end{abstract}

Keywords: Entomopathogenic protozoans, Stored grain insect pests, Mattesia, Spore productivity, Host range, Pathogenicity, Mass-propagation

\section{Background}

Stored products as a unique habitat present a prime opportunity to use entomopathogenic protozoans by distributing infective quantities of the entomopathogen. Hence, controlling stored product insect pests may be most beneficial in long-term storage since such entomopathogenic protozoans produce slow-acting chronic infection. Furthermore, they may cause a reduction in host

\footnotetext{
* Correspondence: dhanmr@yahoo.com

${ }^{3}$ Professor of Economic Entomology Department of Applied Entomology and Zoology, Faculty of Agriculture, Alexandria University, Alexandria, Egypt Full list of author information is available at the end of the article
}

vitality, feeding, fecundity, longevity, and survivorship (McLaughlin, 1971; Khan and Selman, 1989; Flinn and Schöller, 2012; Ramanujam et al., 2014). Weiser et al. (1976) recorded promising examples for certain entomopathogenic protozoans that cause reductions in storage insect pests.

A number of entomopathogenic protozoans, e.g. neogregarines (Mattesia and Farinocystis species), coccidia (Adelina spp.), and microsporidia (Nosema spp.), are known to infect several hosts of storage insects. These entomopathogen species differ in pathogenicity from one host to another; meanwhile, some hosts yield a 
greater number of infective units (spores) than others (McLaughlin, 1971).

The present study was undertaken to evaluate the potential of the Egyptian strain of the neogregarine, Mattesia sp., originally isolated from some stored grain insect pests, namely, spore productivity, pathogenicity, and host range assays and also to mass-propagate the spores of such a locally isolated entomopathogenic protozoan.

\section{Materials and methods}

\section{Insects}

Laboratory cultures of the laemophloeid, Laemophloeus turcicus (Grouvelle), the bostrychid, Rhyzopertha dominica (Fabricius), the tenebrionids, Tribolium castaneum (Herbst) and Tenebrio molitor L., the silvanid or cucujid, Oryzaephilus surinamensis(L.), the cucurculionid, Sitophilus zeamais (Motschulsky), and the pyralid, Plodia interpunctella (Hübner), were originally obtained from a private storehouse of stored grains in KoomHamada, El-Behera Governorate, Egypt, and reared on crushed maize grains. Also, the cultures of the noctuid, Spodoptera littoralis (Boisd.), and the pyralid, Galleria mellonella, (L.) were reared, with respect, on castor bean leaves, Ricinus communis (L.), and beewax. All rearing jars and containers were kept at the laboratory conditions $\left(25.3 \pm 3.8^{\circ} \mathrm{C}, 84.2 \pm 3.7 \% \mathrm{RH}\right.$, and photoperiods of ca. $12-14 \mathrm{~h})$.

\section{The entomopathogenic protozoan, Mattesia sp.}

Mattesia sp. (tentatively, M. dispora) was originally isolated, in Egypt, in 2016, from the insect pests of stored grains (L. turcicus; R. dominica; S. zeamais; P. interpunctella).

\section{Spore counts (spore productivity)}

By using the haemocytometer, the Mattesia-spore counts, per infected host cadaver, were quantified. Each cadaver was thoroughly crushed with a fine, rounded spatula in 1 or $10 \mathrm{ml}$ Ringer solution. Mattesia spores were counted in these suspensions, using a haemocytometer and a light microscope at a magnification of $\times 400$.

\section{Pathogenicity and host range assays as a clue for Mattesia-mass propagation}

Single concentration was adopted to determine the pathogenicity and host range of the isolated entomopathogenic-Mattesia sp. The tested coleopteran adults (L. turcicus, $R$. dominica, and O. surinamensis) of ca. 4to-5-week-old and lepidopteran larvae (P. interpunctella and G. mellonella) of ca.7-to-10-day-old were subjected to a continuous exposure to a fine-crushed maize grains contaminated with a single dose of Mattesia spores ( $0.01 \mathrm{~g}$ of powdered cadavers of Mattesia-infected Laemophloeus adults and $10 \mathrm{~g}$ of fine-crushed maize grains). T. molitor larvae of 7-10-day-old were similarly treated.
S. littoralis larvae of 2-3-day-old were fed continuously on Mattesia spore-contaminated castor bean leaves. The $0.01 \mathrm{~g}$ of such powdered cadavers contained (ca.1.5 $\times 10^{8}$ ) Mattesia spores, based on spore counts with a haemocytometer.

For pathogenicity test, the available numbers of the studied coleopteran and lepidopteran insects were separately treated in groups as follows: 20 (O. surinamensis beetles in $(5 \times 11.5 \mathrm{~cm})$ plastic jars with 3 replicates $), 40$ (L. turcicus beetles in the plastic jars with 5 replicates), 40 (T. molitor larvae in the plastic containers with 5 replicates), 50 ( $R$. dominica beetles in the plastic jars with 5 replicates), 100 ( $P$. interpunctella larvae in $(25 \times 16 \times 11$ $\mathrm{cm})$ plastic containers with 3 replicates), and 50 (S. littoralis larvae in the plastic containers with 3 replicates). The control jars and containers were the same as the treated ones, but with no Mattesia spores. All insects used for the tests were starved for $4 \mathrm{~h}$. All jars or containers were checked 2 weeks post-treatment and then daily for recording mortality rates among treated and untreated insects. Containers of $S$. littoralis were checked daily for providing fresh castor bean leaves when it was needed. The tests were carried out for 3-10 weeks, at the laboratory conditions $\left(22.1 \pm 2.8^{\circ} \mathrm{C}, 81.3 \pm\right.$ $2.7 \%$ R.H., and photoperiods of ca. 12-14 h). Each dead insect, in both the treatments and the controls, was microscopically examined $(100$ and $\times 400)$ for the presence of Mattesia spores.

\section{Responses of Plodia interpunctella larvae to different doses of Mattesia sp.}

Mattesia-infected powdered cadavers of Laemophloeus adults were bio-assayed by inocula of $0.01,0.02,0.04$, 0.08 , and $0.16 \mathrm{~g}$ per container $(20 \times 13 \times 6 \mathrm{~cm})$ supplied with $10 \mathrm{~g}$ fine-crushed maize grains. Spore counts by means of the haemocytometer revealed that the abovementioned inocula contained, respectively (ca.1.5 $\times 10^{8}$, $3 \times 10^{8}, 6 \times 10^{8}, 12 \times 10^{8}$, and $24 \times 10^{8}$ spores). Twentyfive 7-10-day-old $P$. interpunctella larvae, previously starved for $4 \mathrm{~h}$, were introduced into each container. Two replicate containers per inoculum were used. Treated larvae were subjected to a continuous exposure by spore-treated crushed maize grains. The control larvae were treated similarly as the treated ones but without adding Mattesia spores. Mortality was recorded 2 weeks post-treatment and then daily until the larvae had either pupated or the moths emerged, in both the treatments and the controls. Mattesia infection was detected microscopically in all dead or malformed insects. All bioassays were carried out at the laboratory conditions $\left(22.1 \pm 2.8^{\circ} \mathrm{C}, 81.3 \pm 2.7 \%\right.$ R.H., and photoperiods of ca. $12-14 \mathrm{~h})$. Both median lethal concentration $\left(\mathrm{LC}_{50}\right)$ and time $\left(\mathrm{LT}_{50}\right)$ for the tested $P$. interpunctella larvae were 
calculated and percentages of malformed or very smallsized pupae and moths were also recorded.

\section{Bioassay of siftings from protozoan-infected} Laemophloeus stock cultures in Laemophloeus populations Protozoan-infected stock cultures of Laemophloeus were sieved, and siftings were bio-assayed for their efficacy as a potent source of natural mortalities in Laemophloeus populations. Three different concentrations were tested as follows: $0.1 \%(0.1 \mathrm{~g}$ siftings $+99.9 \mathrm{~g}$ crushed maize grains), $1 \%$ ( $1 \mathrm{~g}$ siftings $+99 \mathrm{~g}$ crushed maize grains), and $10 \%$ ( $10 \mathrm{~g}$ siftings $+90 \mathrm{~g}$ crushed maize grains). Three glass jars $(5 \times 11.5 \mathrm{~cm})$ per concentration were prepared; then, each jar was inoculated by 160,4 to 5 weeks old, $L$. turcicus beetles. Control jars were treated by the same treatments but no siftings were added. All assays were carried out at the laboratory conditions $\left(22.1 \pm 2.8^{\circ} \mathrm{C}, \quad 81.3 \pm 2.7 \%\right.$ R.H., and photoperiods of ca.12-14h). All jars, in the controls or the treatments, were checked, starting 2 weeks post-treatment and then weekly, for ca. 6 months. Dead Laemophloeus beetles were recorded. All dead beetles were examined microscopically for the presence of protozoan infection.

\section{Statistical analysis}

All means obtained were compared by the adoption of the $F$ test and $t$ test at the $5 \%$ level of probability, while all probable comparisons among these means were achieved using Duncan's multiple range test, at the 5\% or $1 \%$ level by adopting the computer programme, SPSS 16.0. All data obtained in the bioassays were statistically analysed using the probit analysis statistical method of Finney (1971).

\section{Results and discussion}

\section{Spore counts (spore productivity)}

Data represent average spore counts or yields (Table 1) and range (Table 2) per Mattesia-infected adult, larva, or pupa of the following stored product insect pests: $P$. interpunctella larva, pupa or moth, and G. mellonella larva; $R$. domincia adult; S. zeamais; L. turcicus. Average yields of
Mattesia varied from a minimum yield of spores $(0.17 \times$ $10^{7}$ ), for L. turcicus adult, to a maximum yield of spores $\left(7.46 \times 10^{7}\right)$, for P. interpunctella larva (Table 1$)$. The yield of Mattesia spores averaged $\left(7.46 \times 10^{7} \pm 0.83\right)$ spores per $P$. interpunctella larva or $\left(1.49 \times 10^{7} \pm 0.02\right)$ spores per pupa and $\left(1.45 \times 10^{7} \pm 0.03\right)$ spores moth (Table 1$)$. $P$. interpunctella larva had significantly recorded the highest Mattesia spore yield, than not only its pupal or adult stage but also with the corresponding figures of $S$. zeamais adult $\left(1.48 \times 10^{7} \pm 0.06\right.$ spores $), G$. mellonella larva $\left(1.36 \times 10^{7} \pm\right.$ 0.01 spores $), R$. dominica adult $\left(1.10 \times 10^{7} \pm 0.01\right.$ spores $)$, or L. turcicus adult $\left(0.17 \times 10^{7} \pm 0.02\right.$ spores) (Table 1$)$. Comparatively, the highest increase in Mattesia spore yield, recorded from $P$. interpunctella larva $\left(7.46 \times 10^{7}\right.$ spores) over the lowest one, estimated for L. turcicus adult $\left(0.17 \times 10^{7}\right.$ spores $)$, was nearly 44 -fold, while the increases in Mattesia spore yields, which were calculated for the other hosts (Table 1), over that estimated for L. turcicus adult, were significantly less than 10-fold (6-9-fold) (Table 1).

Range of the calculated increases in Mattesia spore yields for the infected-insect hosts over those achieved for L. turcicus adults was compared and presented in Table 2. As shown in the table, the maximum increases, in terms of folds, of Mattesia spore counts per P. interpunctella larva $\left(0.76-23.6 \times 10^{7}\right.$ spores; ranged from ca. 13-79-fold) relative to spore counts recorded for the smallest and the lightest $(0.1 \pm 0.01 \mathrm{mg})$ (Table 1$)$ examined host, $L$. turcicus $\left(0.06-0.30 \times 10^{7}\right.$ spores $)$, were obviously contrasted to the average spore counts, per host, which had recorded from the other insect hosts (0.84$2.40 \times 10^{7}$ spores; ranged from ca. 4-20-fold) (Table 2). Lord (2003) noted that the grain beetles are small insects, and their use for spore production is laboured and has a limited spore productivity. Furthermore, a larger host might produce many times more spores.

Based on the insect host body weight, $P$. interpunctella larva seemed to be ca. 69-fold heavier than L. turcicus beetle; compared with nearly 16 - or 8 -fold for $R$. dominica beetle or $S$. zeamais weevil, respectively. Assuming an average yield of $7.46 \times 10^{7}$ Mattesia spores

Table 1 Haemocytometer-average spore yield per Mattesia-infected adult, larva, or pupa of certain stored product insect pests

\begin{tabular}{llccl}
\hline Insect pest & Mattesia spore count or yield, mean \pm SE, per adult, larva or pupa & Average body weight (mg) \pm SE per insect host \\
\hline Plodia interpunctella larva & $7.46 \times 10^{7} \pm 0.83 \mathrm{a}$ & Spores & $(44)$ & $6.9 \pm 0.6 \mathrm{mg}\left(10.8 \times 10^{9} \mathrm{spores} / \mathrm{g}\right.$ larva \\
P. interpunctella pupa & $1.49 \times 10^{7} \pm 0.02 \mathrm{~b}$ & Spores & $(9)$ & \\
P. interpunctella moth & $1.45 \times 10^{7} \pm 0.03 \mathrm{~b}$ & Spores & $(9)$ & \\
Galleria mellonella larva & $1.36 \times 10^{7} \pm 0.01 \mathrm{~b}$ & Spores & $(8)$ & $1.6 \pm 0.1 \mathrm{mg}\left(6.9 \times 10^{9} \mathrm{spores} / \mathrm{g}\right.$ beetle \\
Rhyzopertha dominica adult & $1.10 \times 10^{7} \pm 0.01 \mathrm{~b}$ & Spores & $(6)$ & $0.8 \pm 0.2 \mathrm{mg}\left(18.5 \times 10^{9} \mathrm{spores} / \mathrm{g}\right.$ weevil \\
Sitophilus zeamais adult & $1.48 \times 10^{7} \pm 0.06 \mathrm{~b}$ & Spores & $(9)$ & $0.1 \pm 0.01 \mathrm{mg}\left(17.0 \times 10^{9} \mathrm{spores} / \mathrm{g}\right.$ beetle \\
Laemophloeus turcicus adult & $0.17 \times 10^{7} \pm 0.02 \mathrm{~b}$ & Spores & &
\end{tabular}

Data followed by the same letter do not differ significantly at 5 or $1 \%$ level; Duncan's multiple range test 
Table 2 Range of spore counts and their estimated increases (folds) per Mattesia-infected host relative to those of Laemophloeus turcicus

\begin{tabular}{lll}
\hline Insect pest & $\begin{array}{l}\text { Mattesia spore count (range) per } \\
\text { adult, larva, or pupa }\end{array}$ & $\begin{array}{l}\text { Range of estimated increases (folds) in } \\
\text { spore counts relative to } L \text { t turcicus }\end{array}$ \\
\hline Plodia interpunctella larvae & $0.76-23.6 \times 10^{7}$ spores & $13-79$-fold \\
P. interpunctella pupa & $1.20-1.7 \times 10^{7}$ spores & $6-20$-fold \\
P. interpunctella moth & $0.96-1.8 \times 10^{7}$ spores & $6-16$-fold \\
Galleria mellonella larvae & $1.20-1.5 \times 10^{7}$ spores & $5-20$-fold \\
Rhyzopertha dominica adult & $0.96-1.2 \times 10^{7}$ spores & $4-16$-fold \\
Sitophilus zeamais adult & $0.84-2.40 \times 10^{7}$ spores & $8-14$-fold \\
Laemophloeus turcicus adult & $0.06-0.3 \times 10^{7}$ spores & \\
\hline
\end{tabular}

per $P$. interpunctella larva and a larval body weight of ca. $6.9 \mathrm{mg} / \mathrm{larva}$, then an average of $10.8 \times 10^{9}$ spores $/ \mathrm{g}$ larva is probably achieved (Table 1 ). Corresponding averages of $6.9 \times 10^{9}$ spores/g beetle, $18.5 \times 10^{9}$ spores/g weevil, and $17 \times 10^{9}$ spores/g beetle were obtained for $R$. dominica, S. zeamais, and L. turcicus, respectively (Table 1).

Based on the insect body weight and the average spore productivity, it surprisingly appeared that the maximumaverage Mattesia spore yields assumed for $S$. zeamais $(18.5 \times$ $10^{9}$ spores/g weevil) followed by L. turcicus $\left(17.0 \times 10^{9}\right.$ spores/ $\mathrm{g}$ beetle) and $P$. interpunctella $\left(10.8 \times 10^{9}\right.$ spores/g larva) then $R$. dominica $\left(6.9 \times 10^{9}\right.$ spores/g beetle) (Table 1). Although, the results shown in Table 1 reveal that $S$. zeamais weevil or $L$. turcicus beetle had a less body weight, by ca. 9or 69-fold, respectively, and also a less average spore yield, by ca. 5- or 44-fold, respectively, than $P$. interpunctella larva; however, the obtained data for average yield of Mattesia spores/host were not consistent with the assumed ones for Mattesia spores/g host (Table 1). Thus, based on the $1 \mathrm{~g}$ host, the present findings may reveal that the average spore yields (spore productivity) of the entomopathogenic protozoan, Mattesia sp., seemed to be many times more in smaller grain insect hosts than larger ones.

The above-mentioned findings may also be helpful in selecting the most suitable insect host(s) to masspropagate Mattesia sp. for any possible use as a microbial control agent of stored product insect pests or others, as well as to throw light upon Mattesia-host range among populations of stored product insects. Meanwhile, as Mattesia sp. has a broad host range that may cross insect orders among stored product pests (Lord, 2003), it offers the potential for its introduction to suppress several insect pests in storage.

\section{Pathogenicity and host range as a clue for Mattesia-mass propagation}

Mortality responses of 4 coleopteran and 3 lepidopteran insect pests to a single concentration of ca. $1.5 \times 10^{8}$ Mattesia spores per $10 \mathrm{~g}$ crushed maize grain or beewax (or $100 \mathrm{ml}$ Ringer solution) are summarized in Tables 3 and 4.

No protozoan mortality was recorded neither among the controls nor the treated sawtoothed grain beetles, $O$. surinamensis, and larvae of the yellow mealworm, $T$. molitor. Within 32-37 days post-treatment, 100, 81, and $52 \%$ protozoan disease-mortality responses were recorded, respectively, for $L$. turcicus adults, $R$. dominica adults, and $P$. interpunctella larvae (Table 3 ). The data in Table 3 also provide evidence that Mattesia mortality responses increased directly with incubation period, i.e. days post-treatment.

The presence of the characteristic Mattesia spores was confirmed in all smears from dead insects when microscopically examined. These results are in general agreement with the findings of Lord (2003) who reported the Indianmeal moth, $P$. interpunctella, the lesser grain borer,

Table 3 Pathogenicity of a single dose of Mattesia sp. isolated from Laemophloeus turcicus adults versus different insects at indicated days post-treatment

\begin{tabular}{|c|c|c|c|c|}
\hline \multirow[t]{2}{*}{ Insect pest } & \multicolumn{4}{|c|}{ Mortality (\%) at indicated days post-treatment } \\
\hline & 15 & $22-23$ & 27 & $32-37$ \\
\hline Laemophloeus turcicus $^{\mathrm{a}}$ & $46 / 200(23)$ & $53 / 200(27)$ & $64 / 200(32)$ & $200 / 200(100)$ \\
\hline Rhyzopertha dominica ${ }^{a}$ & $43 / 250(17)$ & $137 / 250(55)$ & $185 / 250(74)$ & $202 / 250(81)$ \\
\hline Plodia interpunctella ${ }^{c}$ & $79 / 300(26)$ & $107 / 300(36)$ & $121 / 300(40)$ & $157 / 300(52)$ \\
\hline Oryzaephilus surinamensis ${ }^{a}$ & $0 / 60(0)$ & $0 / 60(0)$ & $0 / 60(0)$ & $0 / 60(0)$ \\
\hline Tenebrio molitor ${ }^{\mathrm{c}}$ & 0/200 (0) & $0 / 200(0)$ & 0/200 (0) & $0 / 200(0)$ \\
\hline
\end{tabular}

a:c Represented in percentages of mortality among treated coleopterous adults: a, of ca. 4-5-week-old and lepidopterous or coleopterous larvae; c, of ca.7-to 10day-old. Mortality in the controls ranged between 0 and $2 \%$

$0.01 \mathrm{~g}$ of powdered cadavers of Mattesia-infected adults of $L$. turcicus (100 cadavers) carried ca. $1.5 \times 10^{8}$ spores per $10 \mathrm{~g}$ of crushed maize grain 
Table 4 Propagation of Mattesia sp. isolated from Laemophloeus turcicus adults in alternate larger insects at indicated inocula and days post-treatment

\begin{tabular}{|c|c|c|c|c|c|c|}
\hline \multirow{3}{*}{$\begin{array}{l}\text { Insect host } \\
\text { (larvae of 7-10-day-old) }\end{array}$} & \multicolumn{6}{|c|}{ Infection rate (\%) at indicated inocula (in $\mathrm{gm})^{*}$ and days post-treatment } \\
\hline & 19-23-day & 19-23-day & 19-23-day & 19-23-day & 19-23-day & 19-23-day \\
\hline & $0.01 \mathrm{~g}$ & $0.02 \mathrm{~g}$ & $0.03 \mathrm{~g}$ & $0.04 \mathrm{~g}$ & $0.05 \mathrm{~g}$ & $0.2 \mathrm{~g}$ \\
\hline Plodia interpunctella & 197/500(39) & $23 / 50(46)$ & & $29 / 50(58)$ & & $667 / 750(89)$ \\
\hline Spodoptera littoralis (larvae of 2-3-day-old) & $0 / 150(0)$ & $0 / 150(0)$ & $0 / 150(0)$ & $0 / 150(0)$ & $0 / 150(0)$ & $0 / 150(0)$ \\
\hline Tenebrio molitor & $0 / 200(0)$ & & & & & $0 / 200(0)$ \\
\hline Galleria mellonella & 0/100 (0) & & & & & 7/100 (7) \\
\hline
\end{tabular}

*Powdered cadavers (in gm) of L. turcicus-Mattesia-infected adults per $10 \mathrm{~g}$ crushed maize grain (or $10 \mathrm{~g}$ beewax for G. mellonella) or $100 \mathrm{ml}$ Ringer solution for S. littoralis-treatments. $0.01 \mathrm{~g}$ of L. turcicus-powdered cadavers (100 cadavers) carried ca. $1.5 \times 10^{8}$ Mattesia spores

R. dominica, and the flat grain beetles, Laemophloeus spp. (Cryptolestes spp.) as susceptible hosts to Mattesia infection. The same author found that adults of $C$. ferrugineus and $O$. surinamensis were similar in their response to Mattesia oryzaephili, with mortality not exceeding 20\%, but differed in their responses to $M$. dispora, with O. surinamensis being more susceptible. The latter result is inconsistent with the present findings. However, based on results of Ormières et al. (1971) that $M$. oryzaephili had reported only from O. surinamensis, and data of Finlayson (1950) that $P$. interpunctella was susceptible to $M$. dispora. The present findings, with those of the other investigators, may give a clue that the type of species of the present genus Mattesia is tentatively most closely aligned with $M$. dispora.

Mattesia-naturally infected stored grain hosts, recorded in this study, are small insects with light body weights (Table 1). In return, their cadavers act as small reservoirs for Mattesia spores, as compared with larger insect hosts. Hence, an attempt to mass-propagate the Mattesia infective units, spores, in alternate larger hosts was carried out, hopefully their spore yields (spore productivity) might be many times more than those of small hosts. Results of this attempt are shown in Table 4, where the mortality responses of the 4 tested larval species to different concentrations of the entomopathogenic protozoan, Mattesia sp., are summarized.

With both the lowest and the highest concentrations of 0.01 and $0.2 \mathrm{~g}$ per $10 \mathrm{~g}$ crushed maize grain (or beewax) or $100 \mathrm{ml}$ Ringer solution, larvae of S. littoralis, T. molitor, and G. mellonella, in general, responded similarly to Mattesia infection with nil mortality responses, 19-23-day post-treatment; only $7 \%$ of the treated-G. mellonella larvae were infected by Mattesia, at the highest test concentration (Table 4). Among the treated larvae, only the P. interpunctella larvae, at all the test concentrations of Mattesia spores, responded, with mortality ranged from 39 to $89 \%$ within 19-23 days post-treatment (Table 4). The data presented in Table 4 also reveal that $P$. interpunctella larval mortality increased directly with increasing concentration.
The presence of Mattesia spores was confirmed in all smears of $P$. interpunctella larval cadavers when examined under the light microscope.

The Indianmeal moth, $P$. interpunctella, had previously reported, by several authors, to be infected, naturally or experimentally, with Mattesia dispora (Musgrave and Mackinnon, 1938, Finlayson, 1950, and Lord, 2003). On the one hand, Lord (2003) found that the secondand third-instar larvae of the greater wax moth, G. mellonella, were highly susceptible to $M$. oryzaephili infection, while their fifth-instar was not. The author had also reported that G. mellonella larvae can serve as a host for mass producing $M$. oryzaephili spores. The findings of the latter author and those of the present study, about the marked difference in pathogenicity or virulence, between $M$. oryzaephili and $M$. dispora towards G. mellonella larvae, may again confirm correctly the tentative identification of the Mattesia type species which was recorded in the present study, and was found mostly closely fits the description of $M$. dispora.

On the other hand, there are no publications on the Egyptian cotton leafworm, S. littoralis, or the yellow mealworm, T. molitor, as hosts for Mattesia spp., except for only one previous report on $M$. oryzaephili in T. molitor. Meanwhile, Lord (2003) reported T. molitor larvae as resistant hosts to $M$. oryzaephili infection, with nil mortality responses, as observed herein. The above-mentioned findings give information on the possible insect host(s) that will be considered as a candidate for propagation of Mattesia sp. which originally isolated, since 2016, from the flour-mill beetle, L. turcicus in Egypt.

\section{Responses of Plodia interpunctella larvae to different doses of Mattesia sp.}

As compared with the Mattesia-infecting coleopteran hosts of stored products, the lepidopteran larvae, pupae, or moths of the Indianmeal moth, $P$. interpunctella, are large hosts featured with significantly great yields of Mattesia spores (Tables 1 and 2). Therefore, $P$. 
interpunctella was suggested to be used as a suitable candidate for Mattesia spores-propagation.

Data in Table 5 summarize the mortality responses of $P$. interpunctella larvae of 7-10-day-old to different Mattesia concentrations, ranging from 0.01 to $0.16 \mathrm{~g}$ powdered cadavers of L. turcicus-Mattesia-infected adults per $10 \mathrm{~g}$ crushed maize grains (carried ca. $1.5 \times 10^{8}$ to $24 \times 10^{8}$ Mattesia spores). The data provide evidence that Mattesia mortality responses, among treated $P$. interpunctella larvae, had increased directly with both the dose and the incubation period (days post-treatment). With the lowest concentration of Mattesia spores (ca. $1.5 \times 10^{8}$ spores per $10 \mathrm{~g}$ crushed maize grain), mortality responses were 28 , 38 , and 48\%, respectively, 15-, 23-, and 37-day posttreatment, whereas the corresponding larval mortality responses with the highest test concentration (ca. $24 \times 10^{8}$ spores $/ 10 \mathrm{~g}$ crushed maize grain), at the same days posttreatment, were, in respect, 60,82 , and $88 \%$ (Table 5). The presence of Mattesia spores was microscopically confirmed in all smears from $P$. interpunctella larval, pupal, or moth cadavers.

Mortality results were analysed by the method of Finney (1971). Values of the median lethal time $\left(\mathrm{LT}_{50}\right)$ and concentration $\left(\mathrm{LC}_{50}\right)$ were estimated in order to obtain more information on the lethal infection of the present Mattesia isolate towards P. interpunctella larvae of 710-day-old, fed on crushed maize grains contaminated with different concentrations of Mattesia spores. Statistically significant probit lines were drawn for larval mortality responses 15,23 , and 37 days post-infection. Details of probit lines are summarized in Table 6. The slopes of the obtained time- or concentration-mortality probit lines were, in general, quite close $(0.71-2.33)$ to those for entomopathogenic protozoans $(0.8-2.1$; Burges and Hussey, 1971). As indicated in Table 6, with Mattesia spore concentrations ranging from $1.5 \times 10^{8}$ to $24 \times$ $10^{8}$ spores $/ 10 \mathrm{~g}$ crushed maize grains, or in other words from 0.01 to $0.16 \mathrm{~g}$ of Mattesia-infected powdered cadavers of $L$. turcicus adults, against $P$. interpunctella larvae of 7-10-day-old, a 50\% mortality responses were achieved 11.13-39.78-day post-treatment $\left(\mathrm{LT}_{50 \mathrm{~s}}\right)$. Also, the data in Table 6 provide evidence that at the highest tested concentration (ca. $24 \times 10^{8}$ spores per $10 \mathrm{~g}$ crushed maize grains), the $\mathrm{LT}_{50}$ value (11.13-day) was reduced nearly to one fourth its value, as compared with the corresponding value (39.78-day) for the lowest tested concentration (ca. $1.5 \times 10^{8}$ spores per $10 \mathrm{~g}$ crushed maize grains). Meanwhile, doubling the tested concentration decreased the time required to attain $50 \%$ mortality $\left(\mathrm{LT}_{50}\right)$ among treated larvae, of P. interpunctella, by nearly $2-14$ days.

Furthermore, the data in Table 6 demonstrate that at the test concentrations below $3 \times 10^{8}$ spores per $10 \mathrm{~g}$ crushed maize grains (i.e. $0.02 \mathrm{~g}$ of Mattesia-infected powdered cadavers of $L$. turcicus adults) or above it, the corresponding $\mathrm{LT}_{50}$ values were not significantly different as their 95\% fiducial limits were overlapped reflecting their relative equality in dose-mortality response or susceptibility to Mattesia isolate. Additionally, the $\mathrm{LT}_{50}$ values presented herein reveal that the higher the Mattesia concentration, the shorter the survival time of lethally infected $P$. interpunctella larvae. At the lowest concentration $\left(1.5 \times 10^{8}\right.$ spores $/ 10 \mathrm{~g}$ crushed maize grain), the $\mathrm{LT}_{50}$ value (39.78-day) was much prolonged by nearly 4 -fold than that (11.13-day) of the highest concentration $\left(24 \times 10^{8}\right.$ spores per $10 \mathrm{~g}$ crushed maize grain).

In this bioassay, the $\mathrm{LC}_{50}$ values at 15 -day and 23 -day post-treatment (ca. 10.35 and $3.3 \times 10^{8}$ spores per $10 \mathrm{~g}$ crushed maize, respectively) were significantly (i.e. nonoverlapping 95\% fiducial limits; Table 6) higher than the corresponding value at 37 days post-treatment (ca. $1.95 \times 10^{8}$ spores $/ 10 \mathrm{~g}$ crushed maize grain) by nearly 5 and 2 -fold, respectively.

On the other hand, the calculated $\mathrm{LC}_{50}$ values at 23or 37-day post-treatment appeared not significantly different (i.e. overlapping 95\% confidence limits; Table 6), although the $\mathrm{LC}_{50}$ value at 23 - day post-treatment was recorded earlier by 14-day than that estimated at 37-day post-treatment. Also, the latter value was lower than the former one by nearly 2 -fold. On analysing the estimated values of $\mathrm{LC}_{50}$, it was observed that the $95 \%$ fiducial limits of $\mathrm{LC}_{50 \mathrm{~s}}$ for $P$. interpunctella-treated larvae are

Table 5 Responses of Plodia interpunctella larvae of 7-10-day-old to doses of Mattesia sp. at indicated days post-treatment

\begin{tabular}{llll}
\hline $\begin{array}{l}\text { Dose }(\mathrm{gm}) * / 10 \mathrm{~g} \\
\text { crushed maize grain } \\
\text { (approx. no. of Mattesia spores) }\end{array}$ & \multicolumn{2}{l}{ Percentage of dead and moribund larvae at indicated days post-treatment } \\
\cline { 2 - 4 } 0.0 (control) & 15 & 23 & 37 \\
$0.01 \mathrm{~g}\left(1.5 \times 10^{8}\right)$ & $14 / 50(0)$ & $19 / 50(0)$ & $0 / 50(0)$ \\
$0.02 \mathrm{~g}\left(3 \times 10^{8}\right)$ & $17 / 50(34)$ & $23 / 50(38)$ & $24 / 50(48)$ \\
$0.04 \mathrm{~g}\left(6 \times 10^{8}\right)$ & $22 / 50(44)$ & $29 / 50(58)$ & $26 / 50(52)$ \\
$0.08 \mathrm{~g}\left(12 \times 10^{8}\right)$ & $26 / 50(52)$ & $37 / 50(74)$ & $35 / 50(70)$ \\
$0.16 \mathrm{~g}\left(24 \times 10^{8}\right)$ & $30 / 50(60)$ & $41 / 50(82)$ & $40 / 50(80)$ \\
\hline
\end{tabular}

*Powdered cadavers (in gm) of Laemophloeus turcicus adults ( $0.01 \mathrm{~g} \simeq 100$ cadavers carried ca. $1.5 \times 10^{8}$ Mattesia spores) 
Table 6 Calculated parameters of the larvicidal activity of Mattesia spores for Plodia interpunctella 7-10-day-old larvae

\begin{tabular}{|c|c|c|c|c|}
\hline \multirow{2}{*}{$\begin{array}{l}\text { Conc. gm* } / 10 \mathrm{~g} \\
\text { crushed maize grain } \\
\text { (approx. no. of } \\
\text { Mattesia spores) }\end{array}$} & \multirow[t]{2}{*}{$\mathrm{LT}_{50}$ (days) } & \multicolumn{2}{|c|}{ 95\% Fiducial limits } & \multirow[t]{2}{*}{ Slope } \\
\hline & & $\begin{array}{l}\text { Lower } \\
\text { (days) }\end{array}$ & $\begin{array}{l}\text { Upper } \\
\text { (days) }\end{array}$ & \\
\hline $0.01 \mathrm{~g}\left(1.5 \times 10^{8}\right)$ & 39.78 & 29.77 & 125.12 & 1.36 \\
\hline $0.02 \mathrm{~g}\left(3 \times 10^{8}\right)$ & 31.65 & 23.85 & 99.13 & 1.17 \\
\hline $0.04 \mathrm{~g}\left(6 \times 10^{8}\right)$ & 18.08 & 12.32 & 21.97 & 1.72 \\
\hline $0.08 \mathrm{~g}\left(12 \times 10^{8}\right)$ & 13.15 & 7.81 & 16.43 & 2.05 \\
\hline $0.16 \mathrm{~g}\left(24 \times 10^{8}\right)$ & 11.13 & 6.52 & 14.12 & 2.33 \\
\hline \multirow[t]{2}{*}{ Days post-treatment } & \multirow{2}{*}{$\begin{array}{l}\mathrm{LC}_{50}(\mathrm{gm}) \text { (approx. no. of } \\
\text { Mattesia spores) }\end{array}$} & \multicolumn{2}{|c|}{ 95\% Fiducial limits } & Slope \\
\hline & & Lower & Upper & \\
\hline \multirow[t]{2}{*}{15} & 0.069 & 0.048 & 0.118 & 0.71 \\
\hline & $\left(10.35 \times 10^{8}\right)$ & \multicolumn{2}{|c|}{$\left(7.2-17.7 \times 10^{8}\right)$} & \\
\hline \multirow[t]{2}{*}{23} & 0.022 & 0.016 & 0.029 & 1.06 \\
\hline & $\left(3.3 \times 10^{8}\right)$ & \multicolumn{2}{|c|}{$\left(2.4-4.35 \times 10^{8}\right)$} & \\
\hline \multirow[t]{2}{*}{37} & 0.013 & 0.009 & 0.018 & 1.08 \\
\hline & $\left(1.95 \times 10^{8}\right)$ & \multicolumn{2}{|c|}{$\left(1.3-2.7 \times 10^{8}\right)$} & \\
\hline
\end{tabular}

*Powdered cadavers of Laemophloeus turcicus adults $\left(0.01 \mathrm{~g} \simeq 100\right.$ cadavers carried ca. $1.5 \times 10^{8}$ Mattesia spores)

sometimes either overlapped, revealing their relative equality in concentration-mortality responses following Mattesia infection, or nonoverlapped and appeared significantly different in their responses or susceptibility to Mattesia sp.

Based on $P$. interpunctella mortality responses and patterns of virulence, $\mathrm{LC}_{50}$ and $\mathrm{LT}_{50}$ values recorded in this study, it could be concluded that the tested larvae of $P$. interpunctella, were considerably susceptible to the entomopathogenic protozoan, Mattesia sp. (tentatively, $M$. dispora) originally isolated, during the present study, from the flour-mill beetle, L. turcicus adults. With Mattesia concentrations ranging from ca. 1.5 to $24 \times 10^{8}$ spores per $10 \mathrm{~g}$ crushed maize grain, nearly 11-40 days were needed to achieve a $50 \%$ mortality response among $P$. interpunctella larvae. The $\mathrm{LC}_{50}$ values were relatively high ranging from 1.95 to $10.35 \times 10^{8}$ spores per $10 \mathrm{~g}$ crushed maize grain; compared with the data reported by Lord (2003) where in single-dose assays of M. oryzaephili $\left(10^{6}\right.$ spores/g diet), greater than $75 \%$ Mattesia infection was achieved 21-day post-treatment for $P$. interpunctella-newly hatched larvae. That may be due to the difference in the larval age of the treated larvae of the present study, 7-10-day-old larvae, and those of Lord (2003), newly hatched larvae. Also, the difference in type species of the genus Mattesia should be taken into consideration, as that of Lord (2003) is M. oryzaephili, while the suggested type species of the present study might be $M$. dispora.

It was fruitful to estimate the average increase of Mattesia spore yields (spore productivity) per $P$. interpunctella larva over inoculation. Therefore, samples of 5 dead or moribund Mattesia-treated P. interpunctella larvae were subjected to procedures of spore counts using the haemocytometer. As Mattesia spore productivity ranged from 14.4 to $18.32 \times 10^{7}$ spores/larva, and the inocula used ranged from 1.5 to $24 \times 10^{8}$ spores per $10 \mathrm{~g}$ crushed maize grain, the increase in spore yields over that used for the inoculum, based on an average of 25 larvae per container, was ca. 2-to 31-fold. These results revealed that the Indianmeal moth, $P$. interpunctella, could serve as a potential host for mass propagating the isolated Mattesia sp. $P$. interpunctella, as one of the most common and destructive insect pests of stored grains and their products, was previously found to be either susceptible to certain Mattesia species, or acting as a naturally harbouring reservoir for Mattesia species that infect several insects associated with stored grains and their products (Musgrave and Mackinnon, 1938; Finlayson, 1950; Lord, 2003).

In the meantime, the observed adverse effects of Mattesia infection on P. interpunctella survivors (Table 7) offer a desirable effect in the field of microbial control of insect pests. Survivors of Mattesia infection suffer deformities and a noticeable small body size than the controls, in their pupal or adult stage. Also, many copulated moths (ca.46\%) were unable to become separated after copulation until they had died (Fig. 1). As seen in Table 7 , percentages of malformed and very small-sized pupae or moths emerged from Mattesia-infected larvae of $P$. interpunctella, 49-63 days post-infection, were clearly not related to dose, i.e. at high or low concentrations of Mattesia spores incorporated with feeding medium. Thus, for $P$. interpunctella-treated larvae, no obvious 
Table 7 Adverse effects of Mattesia infection on Plodia interpunctella survivors

\begin{tabular}{lll}
\hline $\begin{array}{l}\text { Dose }(\mathrm{gm})^{*} / 10 \mathrm{~g} \\
\text { crushed maize grain } \\
\text { (approx. no. of Mattesia spores) }\end{array}$ & Percentage of malformed and very small-sized pupae or moths of $P$. interpunctella at 49-63 days post-treatment \\
\cline { 2 - 3 } $0.0($ control) & 0 & Moths \\
$0.01\left(1.5 \times 10^{8}\right)$ & 60 & 0 \\
$0.02\left(3 \times 10^{8}\right)$ & 67 & 20 \\
$0.04\left(6 \times 10^{8}\right)$ & 0 & 17 \\
$0.08\left(12 \times 10^{8}\right)$ & 0 & 25 \\
$0.16\left(24 \times 10^{8}\right)$ & 33 & 0 \\
\hline
\end{tabular}

*Powdered cadavers (in gm) of Laemophloeus turcicus adults $\left(0.01 \mathrm{~g} \simeq 100\right.$ cadavers carried ca. $1.5 \times 10^{8}$ Mattesia spores)

relationship was found between the recorded rates of pupal or adult deformity and the Mattesia concentration used. At the lowest concentrations of 1.5 or $3 \times 10^{8}$ spores per $10 \mathrm{~g}$ medium, percentages of deformed pupae and adults were 60 and $20 \%$ or 67 and $17 \%$, respectively, whereas the highest concentration of $24 \times 10^{8}$ spores per $10 \mathrm{~g}$ medium exhibited only $33 \%$ malformation among both of the pupae and the adults (Table 7). Meanwhile, the relatively high concentrations of 6 or $12 \times 10^{8}$ spores per $10 \mathrm{~g}$ medium had recorded nil deformity among formed pupae or emerged adults, respectively, except for $25 \%$ deformation among emerged adults had been observed at the latter concentration (Table 7). Thus, no clear trend for the Mattesia inoculum on the resulted percentages of survivor malformations. In the controls, no deformities were observed. On the other hand, smallsized or malformed individuals were found harbouring a profuse number of the characteristic Mattesia spores. Besides Mattesia larval mortality, the malformed survivors are also seemed to be very potential factors in regulating the abundance of insect pest populations, especially populations of stored product insect pests.

These adverse effects of some entomopathogenic protozoans (e.g. neogregarines, coccidia, and microsporidia) on some insect pests have been observed by several investigators. For example, Milner (1972) reported deformations among $T$. castaneum-heavily infected pupae and adults by the microsporidian entomopathogen,
Nosema whitei; also, Rabindra et al. (1981) recorded larval-pupal and pupal-adult intermediate forms among Tribolium spp. infected with the neogregarine, Farinocystis tribolii. Moreover, Listov (1977) stated that the microsporidian parasite, $N$. whitei, and the coccidian one, Adelina tribolii, when administered in the food of secondinstar larvae of Tribolium spp., adultoids were developed in infected pupae.

\section{Bioassay of siftings collected from L. turcicus-protozoan infected stock cultures, in Laemophloeus populations} On the basis of what have been reported by Weiser (1963), Kellen and Lindegren (1971), Schwalbe et al. (1974), Lord (2006) that in confined laboratory cultures, most of stored product insect pests acquired infection by scavenger feeding on infected dry cadavers (Fig. 2) and by ingesting food contaminated with webbing, meconia, as well as faeces that harboured the protozoan infective units, spores or oocysts. Hence, this bioassay has been carried out in order to emphasize the potent role of such protozoan entomopathogens in long-term storage where stored products provide a unique opportunity to use the entomopathogenic protozoans.

Preliminary light microscopic examinations of siftings, from stored-crushed maize grains infested with certain protozoan-infected coleopteran and lepidopteran pests, brought evidence for the presence of Mattesia spores and Adelina oocysts. Three concentrations (0.1, 1, and

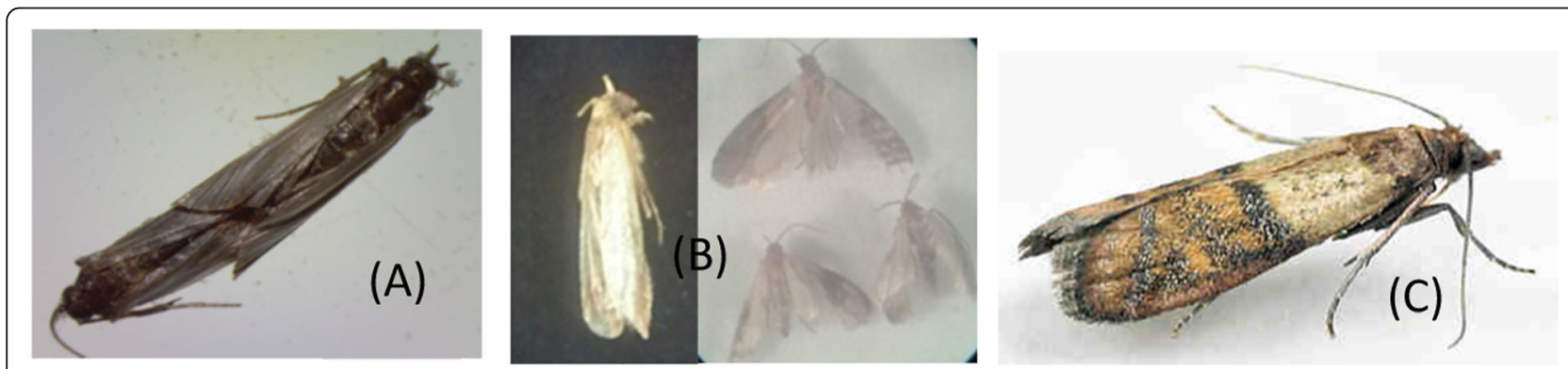

Fig. 1 Failure of Plodia interpunctella moths to be separated after copulation (a). Note the undersized moths (b) and the healthy one (c) (magnification ca. $\times 20)$ 


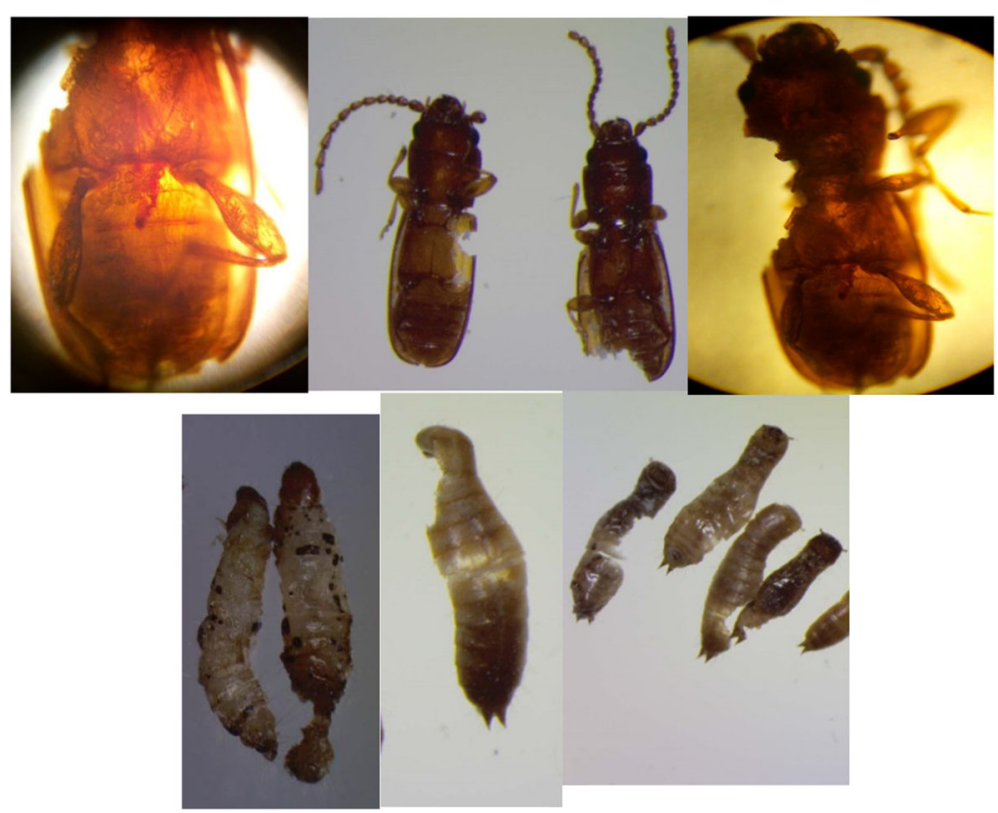

Fig. 2 Cannibalism (scavenger feeding), among most stored product insects, as a desirable manner to acquire protozoan infection (magnification ca. $\times 8-40$ )

$10 \%)$ of this siftings were bio-assayed against $L$. turcicus healthy adults of ca. 4- to 5-week-old. The data in Table 8 indicate that with the lowest concentrations of 0.1 and $1 \%$, mortality responses among Laemophloeustreated beetles, due to Mattesia or Adelina infection, were very low (1-7\%) at 169-day post-treatment. With the highest concentration (10\%), mortality responses, due to Mattesia infection, were ranged from 13 to $68 \%$ at 14-169 days post-treatment, whereas the corresponding figures for Adelina infection were 7-42\%. Unfortunately, the data presented in Table 8 were not adequate to be statistically analysed by the method of Finney (1971); therefore, these data were discussed as percentages of mortality. Seemingly, at 147-days post-treatment (ca.5 months), a 50\% and 39\% of Laemophloeus population had succumbed to death by the entomopathogenic protozoans, Mattesia sp. and Adelina sp., respectively (Table 8).

By no means, the inoculum herein was very low, as it was observed through the microscopic examinations for the studied siftings; thus, the lethal infection had required very long periods to achieve such mortality responses. In spite of these low mortality responses within a remarkably long period of nearly 5 months, or more, but, in long-term control programmes, protozoan entomopathogens are considered as good and important microbial control agents for storage insect pests (McLaughlin, 1971). Frass, faeces, protozoan-infected cadavers, and meconia continuously provide a source of protozoan inoculum; hence, from a control standpoint, this is a desirable demand for regulating, naturally, the abundance of storage insects through a long-term control programme. In this concern,

Table 8 Siftings from protozoan-infected cultures of Laemophloeus turcicus beetles as a potent source of natural mortalities in their populations

\begin{tabular}{|c|c|c|c|c|c|c|c|c|c|c|c|}
\hline \multirow{2}{*}{$\begin{array}{l}\text { Treatment (gm } \\
\text { siftings per } 100 \mathrm{~g} \\
\text { crushed maize grain }\end{array}$} & \multicolumn{11}{|c|}{$\begin{array}{l}\text { \% Mortality among laemophloeus beetles due to the } \\
\text { entomopathogenic protozoan, Mattesia (M), or Adelina (A) at indicated days post-treatment }\end{array}$} \\
\hline & $14-15$ & $19-22$ & 28 & $30-35$ & $41-56$ & 70 & 84-98 & 140 & 147 & 162 & 169 \\
\hline 0.0 (control) & - & - & - & - & - & - & - & - & - & - & $4^{*}$ \\
\hline \multirow[t]{2}{*}{$0.1 \%$} & - & $2(\mathrm{M})$ & $4(M)$ & $4(M)$ & $4(M)$ & $4(\mathrm{M})$ & $4(M)$ & $4(M)$ & $4(M)$ & $4(M)$ & $4(M)$ \\
\hline & & & $1(\mathrm{~A})$ & $1(\mathrm{~A})$ & $1(\mathrm{~A})$ & $1(\mathrm{~A})$ & $1(\mathrm{~A})$ & $1(\mathrm{~A})$ & $1(A)$ & $1(\mathrm{~A})$ & $1(\mathrm{~A})$ \\
\hline $1 \%$ & $3(\mathrm{M})$ & $4(M)$ & $5(M)$ & $6(M)$ & $7(M)$ & $7(\mathrm{M})$ & $7(\mathrm{M})$ & $7(M)$ & $7(\mathrm{M})$ & $7(\mathrm{M})$ & $7(\mathrm{M})$ \\
\hline \multirow[t]{2}{*}{$10 \%$} & $13(\mathrm{M})$ & $16(\mathrm{M})$ & $19(\mathrm{M})$ & $22(\mathrm{M})$ & $30(M)$ & $38(\mathrm{M})$ & $44(M)$ & $46(\mathrm{M})$ & $50(\mathrm{M})$ & $53(\mathrm{M})$ & $68(M)$ \\
\hline & $7(A)$ & $8(A)$ & $8(A)$ & $8(A)$ & $8(A)$ & $9(A)$ & $21(\mathrm{~A})$ & $31(\mathrm{~A})$ & $39(\mathrm{~A})$ & 41 (A) & $42(\mathrm{~A})$ \\
\hline
\end{tabular}

*Protozoan free natural mortality 
siftings might be considered as a potent source of protozoan infective unit dissemination (i.e. autodissemination) which eventually leads to infections in natural populations of stored product insect pests; such infection rates may range from a low incidence to an epizootic. On the other hand, several neogregarine, coccidian, and microsporidian natural infections, among populations of storage insect pests, are usually sparse but occasionally may become epizootics Burges and Hussey (1971).

In conclusion, the present study had thrown the light upon the following findings and approaches which could potentially be helpful in microbial control of storage insect pests: (1) on the basis of a $1 \mathrm{~g}$ insect host infected with the entomopathogen, Mattesia sp., small stored grain insect hosts (e.g. L. turcicus, S. zeamais, and R. dominica) seem to achieve Mattesia spore yields (spore productivity) many times more than larger ones (e.g. P. interpunctella); (2) the powdery preparations of protozoan-infected cadavers of stored product insect pests showed considerable mortalities among populations of these pests; therefore, both the natural and the artificial spread of such entomopathogens in stored product insect populations should manage to be utilized as a potential regulating source for these economic pest populations; (3) the recorded-survivor malformations or adverse effects of Mattesia infection on $P$. interpunctella survivors performed a desirable effect in the field of microbial suppression for the insect pests in storage; (4) the siftings and the protozoaninfected cadavers of insect pests in storage are very potential sources in regulating the abundance of such insect pest populations, especially through long-term control programmes.

\section{Conclusion}

A considerable degree of natural or applied microbial control by the entomopathogenic protozoans was recorded among some coleopteran and lepidopteran stored product pests. On the one hand, some protozoaninfected hosts yield greater numbers of protozoan infective units, spores or oocysts, than others. On the other hand, the entomopathogenic protozoans infective in certain insect species vary in pathogenicity from host to another. Besides death of the insect host, survivors of the protozoan disease would suffer other important effects which are desired in the field of microbial suppression of insect pests in storage. Protozoan-diseased insect cadavers, moribund insects, and siftings are important reservoirs for the protozoan infective units in habitats of stored products. Such natural reservoirs are very potential sources in regulating the abundance of insect pest populations in storage, especially through long-term control programmes. The relatively slow action of the protozoan disease seems beneficial for biological control of stored product insect pests.
Acknowledgements

Not applicable

Authors' contributions

All authors agreed to publish the manuscript. All authors read and approved the final manuscript.

\section{Funding}

Not applicable

Availability of data and materials

Not applicable

Ethics approval and consent to participate

Not applicable

Consent for publication

Not applicable

\section{Competing interests}

The authors declare that they have no competing interests.

\section{Author details}

${ }^{1}$ Emeritus Professor of Economic Entomology Department of Applied Entomology and Zoology, Faculty of Agriculture, Alexandria University, Alexandria, Egypt. ${ }^{2}$ Department of Applied Entomology and Zoology, Faculty of Agriculture, Alexandria University, Alexandria, Egypt. ${ }^{3}$ Professor of Economic Entomology Department of Applied Entomology and Zoology, Faculty of Agriculture, Alexandria University, Alexandria, Egypt.

Received: 29 May 2019 Accepted: 29 November 2019

Published online: 24 December 2019

\section{References}

Burges HD, Hussey NW (1971) Microbial control of insects and mites. New York: Academic Press; pp. 861

Finlayson LH (1950) Mortality of Laemophloeus (Coleoptera, Cucujidae) infected with Mattesia dispora Naville (Protozoa, Schizogregarinaria). Parasitology 40: 261-264

Finney DJ (1971) Probit analysis. Cambridge University Press, London, New York

Flinn PW, Scholler M (2012) Biological control: Insect pathogens, parasitoids and predators. Kansas State University Agricultural Experiment Station and Cooperative Extension Service S156. pp.1-10

Kellen WR, Lindegren JE (1971) Modes of transmission of Nosema plodiae Kellen and Lindegren, a pathogen of Plodia interpunctella (Hübner). J Stored Prod Res 7:31-34

Khan AR, Selman BJ (1989) Nosema spp.(Microspora:Microsporidia: Nosematidae) of stored product Coleoptera and their potential as microbial control agents. Agric Zool Revs 3:193-223

Listov MV (1977) The effect of pathogenic protozoa on the hormonal balance of flour beetles (Coleoptera, Tenebrionidae). Rev Appl Entomol 66(11):5622

Lord JC (2003) Mattesia oryzaephili (Neogregarinorida: Lipotrophidae), a pathogen of stored-grain insects: virulence, host range and comparison with Mattesia dispora. Biocontrol Sci Tech 13:589-598

Lord JC (2006) Interaction of Mattesia oryzaephili (Neogregarinorida: Lipotrophidae) with Cephalonomia spp. (Hymenoptera:Bethylidae) and their hosts Cryptolestes ferrugineus (Coleoptera: Laemophloeidae) and Oryzaephilus surinamensis (Coleoptera: Silvanidae). Biol. Control 37:167-172

McLaughlin RE (1971) Use of protozoans for microbial control of insects. In: Burges HD, Hussey NW (eds) Microbial control of insects and mites. Academic Press, New York, pp 151-172

Milner RJ (1972) Nosema whitei, a microsporidian pathogen of some species of Tribolium: III. Effect on T. castaneum. J Invertebr Pathol 19:248-255

Musgrave AJ, Mackinnon DL (1938) Infection of Plodia interpunctella (Hbn.) (Lepidoptera: Phycitidae) with a schizogregarine Mattesia dispora Naville. Proc. Roy. Entomol. Soc. London 13:89-90

Ormieres R, Louis C, Kuhl G. (1971) Mattesia oryzaephili n. sp., neogregarine parasite d' Oryzaephilus surinamensis L. (Coleoptera: Cucugidae). Cycle et action pathogene, Bull Soc Zool Fr 96:547-556 
Rabindra RJ, Balasubramanian M, Jayaraj S (1981) The effects of Farinocystis tribolii on the growth and development of the flour beetle Tribolium castaneum. J Invertebr Pathol 38(3):345-351

Ramanujam B, Rangeshwaran R, Sivakmar G, Mohan M, Yandigeri MS (2014) Management of insect pests by microorganisms. Proc Indian Nat Sci Acad 80(2):455-471

Schwalbe CP, Burkholder WE, Boush GM (1974) Mattesia trogodermae infection rates as influenced by mode of transmission, dosage and host species. J Stored Prod Res 10:161-166

Weiser J (1963) Sporozoan infections. In: Steinhaus EA (ed) Insect pathology: an advanced treatise. II. Academic Press, London, pp 291-331

Weiser J, Bucher GE, Poinar GO (1976) Host relationships and utility of pathogens. In: Huffaker CB, Messenger PS (eds) The theory and practice of biological control. Academic Press, New York, pp 169-185

\section{Publisher's Note}

Springer Nature remains neutral with regard to jurisdictional claims in published maps and institutional affiliations.

\section{Submit your manuscript to a SpringerOpen ${ }^{\circ}$ journal and benefit from:}

- Convenient online submission

- Rigorous peer review

- Open access: articles freely available online

High visibility within the field

- Retaining the copyright to your article

Submit your next manuscript at $\boldsymbol{\nabla}$ springeropen.com 